\title{
Effect of Welding Parameters of Resistance Spot Welding on Mechanical Properties and Corrosion Resistance of $316 \mathrm{~L}$
}

\author{
Safaa M Hassoni ${ }^{a}$, Osamah Sabah Barrak ${ }^{a *}$ (D), Muammar Ibrahim Ismail ${ }^{a}$, Sabah Khammass Hussein ${ }^{b}$ \\ ${ }^{a}$ Middle Technical University, Institute of Technology - Baghdad, Baghdad, Iraq. \\ ${ }^{b}$ Middle Technical University, Engineering Technical College-Baghdad, Baghdad, Iraq.
}

Received: March 08, 2021; Revised: December 10, 2021; Accepted: February 06, 2022

\begin{abstract}
The purpose of this research is to analyze the mechanical properties and corrosion resistance of spot welding of stainless steels AISI 316L using the process of resistance spot welding varying welding parameters with three level for each of welding parameter; welding current (A.), electrode Pressure (bar), squeeze time (s.), and welding time (s.). The welding current was (4500, 5500 and 6500) A, the electrode Pressure was (20, 30 and 40) bar, the squeeze time was (0.6, 0.8 and 1) Sec., and the welding time was $(0.3,0.6$ and 0.9$)$ Sec. The specimens were inspected by a tensile-shear test, corrosion test and the inspection of scanning electron microscope (SEM). The technique of design of the experiments (DOE) was utilized to examine the influence of the welding process parameters on the joint tensile-shear force. The results were analyzed by the DOE method to determine the optimum tensile-shear force, where can be obtained by utilizing the welding parameters by welding current $5500 \mathrm{~A}$, electrode pressure of 30 bar, squeeze time $0.8 \mathrm{~s}$., and welding time of $0.3 \mathrm{~s}$. The examination of SEM indicated that the increment of welding current and electrode pressure leads to increment pitting and corrosion rate.
\end{abstract}

Keywords: RSW, Similar Stainless Steels, DOE, Corrosion Test, SEM.

\section{Introduction}

Resistance spot welding (RSW) method is a propagated utilized joining process in metals welding with a thin thickness to structure manufacturing, particularly in the automotive, ship-building, and lightweight industries ${ }^{1,2}$. At present, the industries are aiming to minimize the cost together weight with a compromise between of high performance and safety. The welding process was achieved by an enormous electric current flow through touching the sheet metals to heat up and compose a molten nugget ${ }^{3-5}$. Regularly, the steel body of the vehicle usually contains about 5,000 spot welds to join sheets of various thickness, and the spot welds quality dramatically influence the reliability and safety of an automotive structure ${ }^{6,7}$. In the process of RSW, two or more metals pieces clamped between two electrodes of copper. The pressure on the metal pieces is applied through the electrode and then flowing an adequate current for welding the metal. The concatenation of the RSW operations are; Work-piece Setup, "Squeezing, Welding, Holding, and offtime". The welding quality principally relies upon the welding parameters that include "welding current, electrode pressure, squeeze time, and welding time" "8-11. Thus, the requirement of welding quality is essential for automobiles, rail vehicles, truck cabins, home appliances, shipbuilding industries, and others. The researchers attempted to study the influence of the welding process parameters including "welding current, electrode pressure, squeeze time, and welding time" on the spot welding of metal such as carbon and stainless steel (St.St.). There is no noticeable relationship between the thickness of the welding nugget and welding time. In any case, the thickness of welding nugget was found to diminish with the growing welding current. The principal motivation of researches is the optimization of weld quality ${ }^{12-16}$.

RSW is recognized by low input of heat contrasted with the other methods of welding, that lead to detrimental effects related to higher heat input, such as residual stresses and high temperature oxidation. In the process of RSW, the spot-welded nuggets properties are the main significant factors that determine the quality of the weld, which relies upon the nugget microstructure influenced by cooling rates and thermal processes. Likewise, the surface of St.St. is privately heated and a film of colored oxide formed called "heat tinting". The corrosion resistance of heat-tinted regions is minimized and be extra oversensitive to the corrosion than the uninfluenced base material $^{17-21}$.

Since the welding is a discontinuity point, and with a large number of spot welding in the structural body of a vehicle, which is directly participatory in the transmission of loads in the event of a crash, its integrity and performance of mechanical are the extreme significance to include the sufficient passenger safety. Furthermore, noise, harshness, and vibration of a vehicle can be influence by the inconvenient quality of spot welds. The phenomena of corrosion can increase negative problems because it significantly diminishes the strength of spot weld and its ability to soak up energy through a car accident. In such a manner, corrosion can cause alloying metal loss from spot welds and / or reason the crack form, thereby diminution the cross-section area that withstands outer loads. When considering the limited spot welds size, this portion should be contemplated with careful attention ${ }^{22-25}$. 
Table 1. The chemical composition of AISI 316L.

\begin{tabular}{|c|c|c|c|c|c|c|c|c|c|c|}
\hline Element wt $\%$ & $\mathrm{C}$ & $\mathrm{Cr}$ & $\mathrm{Ni}$ & Mo & $\mathrm{Mn}$ & $\mathrm{P}$ & $\mathrm{Si}$ & $\mathrm{S}$ & $\mathrm{N}$ & $\mathrm{Fe}$ \\
\hline AISI 316L & 0.026 & 17.3 & 11.2 & 2.42 & 1.15 & 0.027 & 0.5 & 0.022 & 0.07 & Bal. \\
\hline
\end{tabular}

Welding process parameters can influence the corrosion resistance of the spot welding since the parameters influence the size and shape of the joint, as well as the Cr coating amount that evaporates through the welding process and its spoil. "Additionally, inappropriate welding regulation can lead the metal to be expelled and the figuration of metal splashes about the welding zone, at the interface of the two metal sheets, resulting in further damage to the Cr coating"'26-28. The literature converged on the corrosion resistance of St.St. sheets, often joints indicating the corrosion behavior, nearby the spot welds in the areas between the overlapped of two metal sheets, and the influence of expulsion the metal on it.

This present work aims to investigate the tensile-shear force and corrosion resistance of welded similar AISI 316L sheets by RSW studying the welding parameters effect (welding current, Electrode Pressure, and Squeeze time). Furthermore, utilized a program of Minitab to achieve method the design of experimental (DOE) to notice the effect of welding parameters on the tensile-shear force of joint. The corrosion test and SEM were performed to investigate the effect of the welding process parameters on the corrosion resistance of the welding nugget zone.

\section{Experimental Procedure}

\subsection{Materials}

In this work, the base metal was austenitic stainless steel (ASS) AISI 316L sheet with a thickness of $(0.5) \mathrm{mm}$. Tables 1 and 2 , respectively, illustrate this base metal's chemical composition and mechanical properties. The spectroscopic method was applied to perform the chemical composition analysis.

\subsection{Welding process}

The base metal was singly cut into plates of dimensions $(76 * 16) \mathrm{mm}(\mathrm{LxW})$ and lap-jointed with dimensions (16*16) $\mathrm{mm}$ according to the (AWS C1.1M/C1.1:2012 standard). The welded specimens were obtained by RSW, as shown in Figure 1, "the electrode was a dome shape with $4 \mathrm{~mm}$ circular contacting area RWMA GROUP A class 2 type B, made from chromium-zirconium-copper alloy"29.

Before welding the specimens, Minitab's software for the DOE mode was applied for welding parameters to distinguish the effect weld parameters on the mechanical properties, where the welding parameters of RSW utilized in this research were four parameters; "welding current (A.), electrode Pressure (bar), squeeze time (s.), and welding time (s.)". Table 3 indicated the spotwelding parameters after applied the Taguchi process was applied as a tool of DOE used to prepare welding samples.

\subsection{Experimental test}

\subsubsection{Tensile-Shear test}

The tensile-shear tests were performed on specimens of spot welding at a speed of crosshead $10 \mathrm{~mm} / \mathrm{min}$ in a
Table 2. Mechanical properties AISI 316L

\begin{tabular}{cccc}
\hline $\begin{array}{c}\text { Material } \\
\text { Property }\end{array}$ & $\begin{array}{c}\text { Yield Strength } \\
\sigma_{\mathrm{y}},(\mathrm{MPa})\end{array}$ & $\begin{array}{c}\text { Tensile Strength } \\
\sigma_{\mathrm{u}},(\mathrm{MPa})\end{array}$ & $\begin{array}{c}\text { Elongation } \\
\text { EL },(\%)\end{array}$ \\
\hline AISI 316L & 283 & 631 & 31 \\
\hline
\end{tabular}

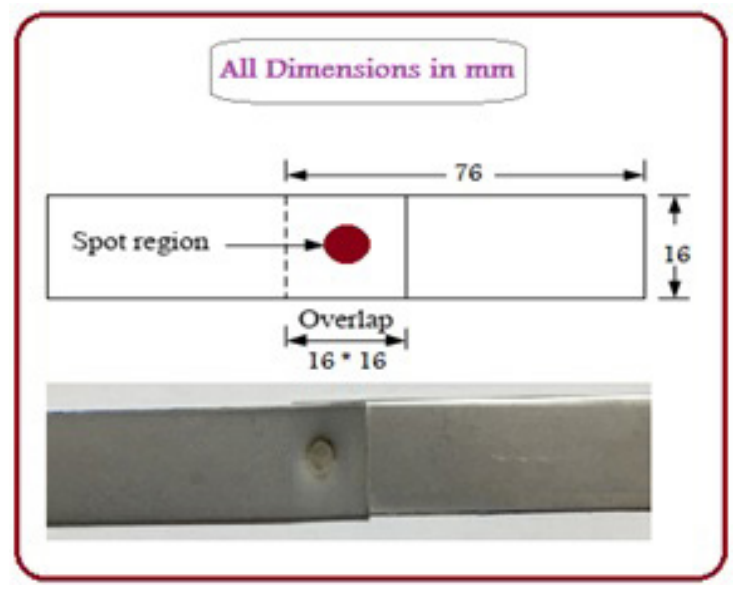

Figure 1. Sample of RSW.

WDW-300Y Series, Universal Testing Machine with load capacity $20 \mathrm{KN}$, China). The specimens were grasped with shims of a thickness equivalent to that of the welding specimens.

\subsubsection{Corrosion test}

Specimens were prepared from welds and according to the welding conditions indicated above, they were mounted, and a corrosion test was conducted in a DY2300 Series potentiostat/Bi potentiostat, USA), for the two samples that achieved the highest and lowest value of tensile-shear tests and the exposed area $1 \mathrm{~cm}^{2}$ by using potentiated and cyclic anodic polarization technique according to ASTM G $5-94^{30}$ standard, to obtain the values of Icorr, Ecorr, Epitt and calculate the corrosion rate for each Specimen. The aqueous medium for the immersion was prepared with artificial seawater $(3.5 \% \mathrm{NaCl})$, Which consists of 35 grams of sodium chloride salt with $1000 \mathrm{ml}$ of distilled water, and the degree of $\mathrm{pH}$ was measured and found to be equal to 6.5. Then the Scanning Electron Microscope (SEM) inspection was utilized to examination the cross-section joint microstructure, to determine the joint interface, and to detect the influence of corrosion at the nugget zone.

\section{Results and Discussion}

\subsection{Tensile-Shear test}

Tensile-shear tests demonstrated that all the samples had an estimate of tensile-shear force, which differs from specimen to 
sample. Figure 2 presents the tensile-shear force estimates of the samples as indicated by the number of samples in Table 3. Specimen 9, which was welded with the following welding parameters: welding current $6500 \mathrm{~A}$, electrode pressure of 40 bar, squeeze time $0.8 \mathrm{~s}$., and welding time of $0.3 \mathrm{~s}$., displayed the minimum tensile-shear force estimate $(3.1 \mathrm{kN})$. The maximum tensile-shear force estimate $(5.1 \mathrm{kN})$ was observed in sample 2 , which was welded at welding current $4500 \mathrm{~A}$, electrode pressure of $30 \mathrm{bar}$, squeeze time $0.8 \mathrm{~s}$., and welding time of (0.6s).

\subsection{Taguchi analysis}

Taguchi investigation was achieved utilizing Minitab $^{31}$ software to examine the influence of spot-welding parameters on the tensile-shear force of the lap joint and decide the optimal amount (level) of RSW parameters which award the preferable tensile-shear force, as appeared in Figure 3. The outcomes elucidated that all the RSW parameters have an alternative influence on the tensile-shear force of the welds as indicated by their levels. The tensile-shear force was enhanced by augmenting the electrode pressure from 20 to 30 bar, welding current from 4500 to $5500 \mathrm{~A}$, squeeze time

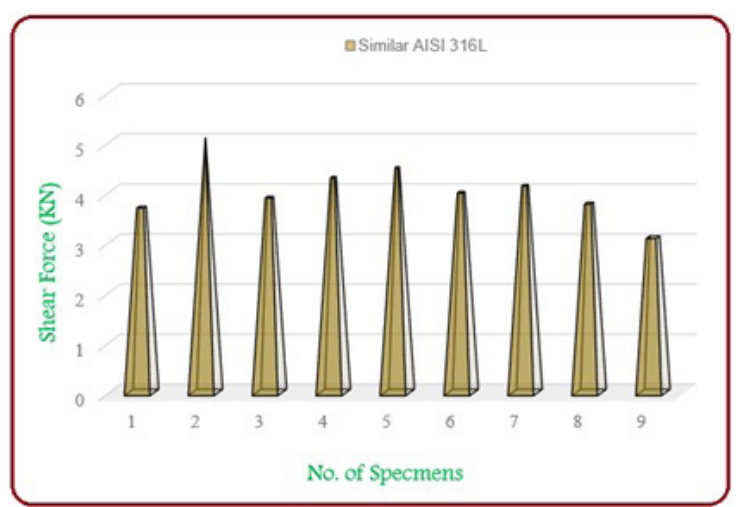

Figure 2. Results of tensile-shear force. from 0.6 to 1 s., and welding time from 0.3 to 0.6 second. Different "levels of the RSW parameters diminished the tensile-shear force of the samples. The main effect plot specified the optimum RSW parameters that resulted in the optimum tensile-shear force of the "welding at RSW parameters of electrode pressure from 30 bar, welding current $5500 \mathrm{~A}$, squeeze time from $1 \mathrm{~s}$., and welding time 0.6 second.

\subsection{Corrosion analysis}

After performing the corrosion tests by using potentiated technique, two curves for samples no. 2 and no. 9 were obtained as shown in Figure 4.

And there were other two curves for samples 2 and 9 when it tested by cyclic anodic polarization technique as plotted in Figure 5.

And with the help of the curves that appeared in the above figures, the values of Icorr, Ecorr, Epitt and the corrosion rate of samples 2 and 9 were obtained, as shown in the Table 4 .

After performing the corrosion tests with the help of the high-magnification SEM image, the pitting regions that appeared in both samples 2 and 9 and in both the weld area and the areas close to it were observed, as shown in Figure 6.

From the obtained values for the corrosion test, it was found that the corrosion rate of sample no.9 is higher than it is in sample 2 can be seen clearly in Figure 6 for the SEM. And the pitting corrosion value occurred in the sample surface of the weld area and its adjacent areas, as shown in Figure 6; it can be seen the sample 2 has less pitting corrosion. This led to the sample 2 obtain on the best tensile-shear force from sample 9. It is also known that St.St. can be susceptible to seawater corrosion ${ }^{32}$. Since the welding conditions of sample 9 in terms of the welding current and electrode pressure used for welding were higher and consequently the thermal stresses were higher than the sample 2, so the pitting which appeared on the surface was more intense and also the corrosion rate even though the exposure time to the current was lower.

Table 3. Welding Parameter.

\begin{tabular}{ccccc}
\hline No. & Welding Current (A) & Pressure (bar) & Squeeze time (s.) & Welding time (s.) \\
\hline 1 & 4500 & 20 & 0.6 & 0.3 \\
\hline 2 & 4500 & 30 & 0.8 & 0.6 \\
\hline 3 & 4500 & 40 & 1 & 0.9 \\
\hline 4 & 5500 & 20 & 1 & 0.9 \\
\hline 5 & 5500 & 30 & 0.6 & 0.3 \\
\hline 6 & 5500 & 40 & 1 & 0.6 \\
\hline 7 & 6500 & 20 & 0.6 & 0.6 \\
\hline 8 & 6500 & 30 & 0.8 & 0.9 \\
\hline 9 & 6500 & 40 & 0.3 \\
\hline
\end{tabular}

Table 4. The Values obtained from tests curves the potentiated and cyclic anodic polarization technique.

\begin{tabular}{ccccc}
\hline Sample & Icorr. $\mu \mathrm{A}$ & Ecorr.mV. & Epitt.mV. & C.R. m.d.d. \\
\hline no.2 & 310.8 & -1031.8 & 189.1 & 130.6 \\
\hline no.9 & 331.45 & -980.4 & 202.9 & 139.26 \\
\hline
\end{tabular}




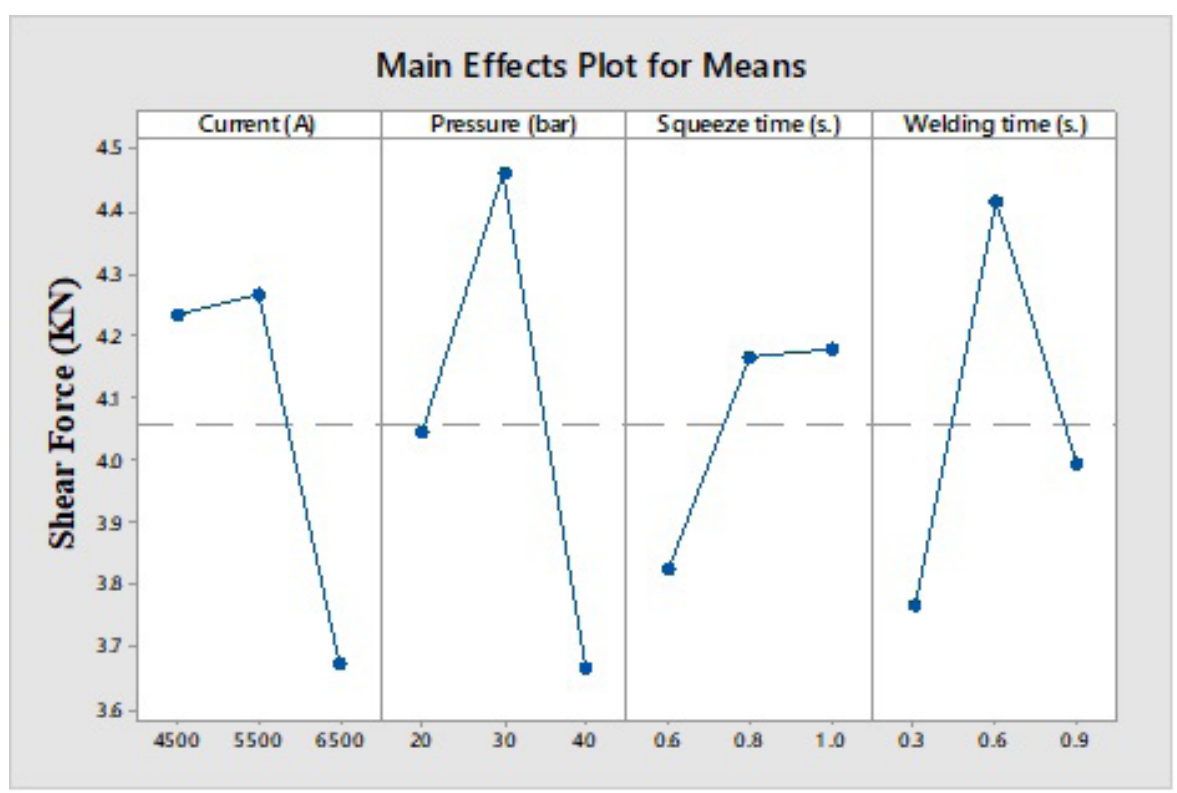

Figure 3. Effect plot of the welding parameters on the tensile-shear force.

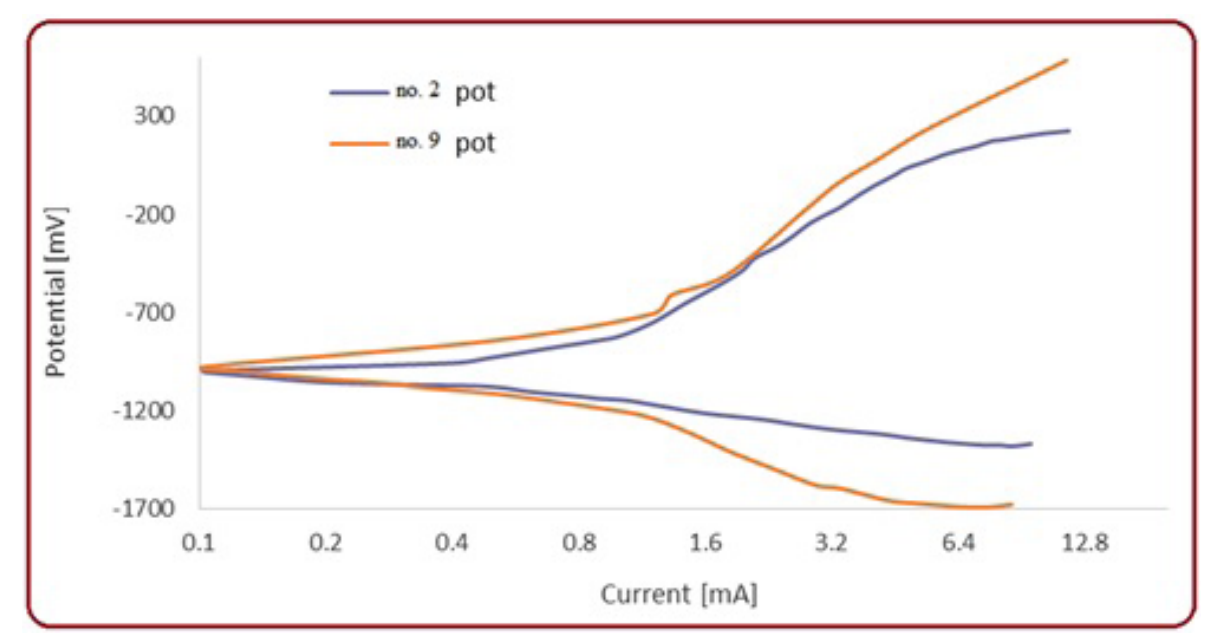

Figure 4. The potential study for samples 2 and 9.

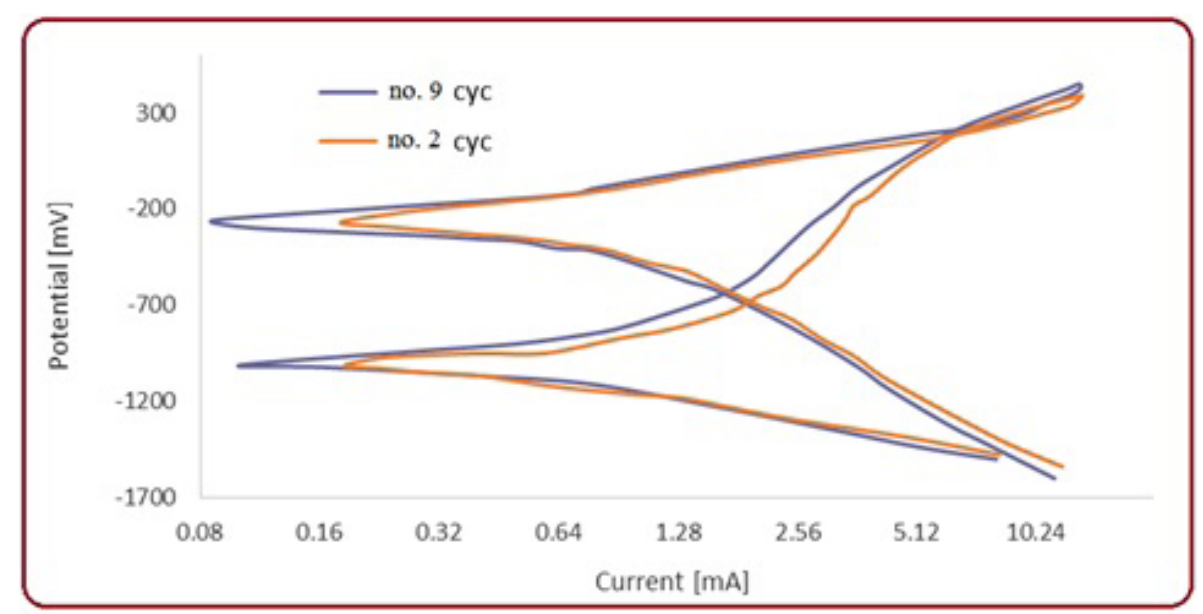

Figure 5. The cyclic test for two samples no.2 and no.9. 


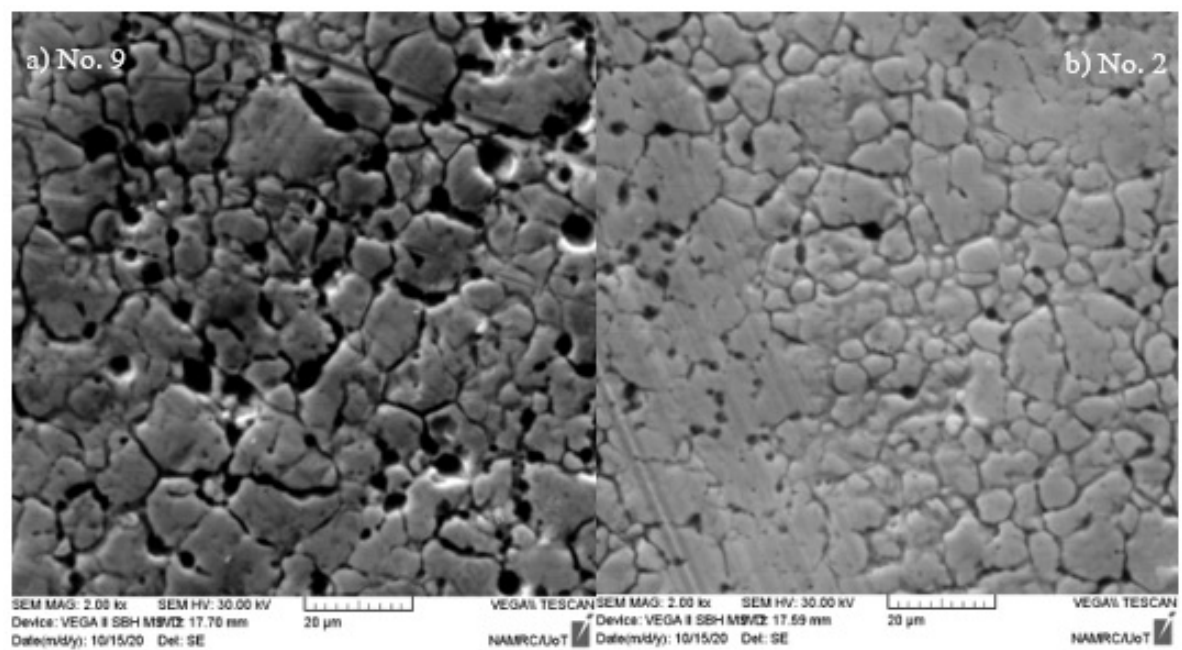

Figure 6. SEM of the two samples no. 2 and no. 9 after corrosion test.

\section{Conclusions}

The RSW process was used to join similar AISI 316L. The effect of welding parameters of the RSW method on the joint tensile-shear force and corrosion resistance were investigated. The following conclusions were noted:

1- The highest tensile-shear force estimate of the joint $(5.1 \mathrm{kN})$ was observed, that was welded at welding current $4500 \mathrm{~A}$, electrode pressure of $30 \mathrm{bar}$, squeeze time $0.8 \mathrm{~s}$., and welding time of $(0.6 \mathrm{~s})$.

2- The lowest tensile-shear force estimate of the joint $(3.1 \mathrm{kN})$ was observed, which was welded at welding current $6500 \mathrm{~A}$, electrode pressure of $40 \mathrm{bar}$, squeeze time $0.8 \mathrm{~s}$., and welding time of $0.3 \mathrm{~s}$.

3- The tensile-shear force has been optimized by applying Taguchi investigation, which specified the welding parameters such as welding current $5500 \mathrm{~A}$, electrode pressure of $30 \mathrm{bar}$, squeeze time $0.8 \mathrm{~s}$., and welding time of $0.3 \mathrm{~s}$.

4- The corrosion rate and pitting corrosion at sample 9 more than in sample 2 .

5- Increased welding current of the RSW process leads to increased pitting and corrosion rate.

6- Increased electrode pressure of the RSW process leads to increased pitting and corrosion rate.

\section{References}

1. Zhou K, Shi T, Cai L. Online measuring the electrical resistivity of molten nugget of stainless steel in resistance spot welding. J Manuf Process. 2017;28:109-15. http://dx.doi.org/10.1016/j. jmapro.2017.05.026.

2. Pouranvari M. Analysis of fracture mode of galvanized low carbon steel resistance spot welds. Int J Multidiscip Sci Eng. 2011;2:36-40.

3. Vigneshkumar M, Varthanan PA. Comparison of RSM and ANN model in the prediction of the tensile shear failure load of spot welded AISI 304/316 L dissimilar sheets. Int J Comput Mater Sci Surf Eng. 2019;8(2):114-30. http://dx.doi.org/10.1504/ IJCMSSE.2019.102292.

4. Barrak OS, Sar MH, Saad ML, Hussein AK, Hussein SK. Using brass foil interlayer to improve the resistance spot welding
AA5451 with apply taguchi method. J Mech Eng Res Dev. 2019;42(3):120-4.

5. Barrak OS, Saad ML, Mezher MT, Hussein SK, Hamzah MM. Joining of double pre-holed aluminum alloy AA6061-T6 to polyamide PA using hot press technique. IOP Conf Series Mater Sci Eng. 2020;881(1):012062.

6. Wang B, Lou M, Shen Q, Li YB, Zhang H. Shunting effect in resistance spot welding steels - Part 1: experimental study. Weld J. 2013;92(6):1-8.

7. Hussein SK, Barrak OS. Optimization the resistance spot welding parameters of austenitic stainless steel and aluminum alloy using design of experiment metho. Eng \& Tech Journal. 2016;34(7):1383-401.

8. Kaya Y, Kahraman N. The effects of electrode force, welding current and welding time on the resistance spot weldability of pure titanium. Int J Adv Manuf Technol. 2012;60(1-4):127-34. http://dx.doi.org/10.1007/s00170-011-3604-z.

9. Hussein SK, Barrak OS. Analysis and optimization of resistance spot welding parameter of dissimilar metals mild steel and aluminum using design of experiment method. Engineering and Technology Journal. 2015;33(8):1999-2011.

10. Bina MH, Jamali M, Shamanian M, Sabet H. Effect of welding time in the resistance spot welded dissimilar stainless steels. Trans Indian Inst Met. 2015;68(2):247-55. http://dx.doi.org/10.1007/ s12666-014-0452-1.

11. Wei ST, Liu RD, Lv D, Lin L, Xu RJ, Guo JY et al. Weldability and mechanical properties of similar and dissimilar resistance spot welds of three-layer advanced high strength steels. Sci Technol Weld Join. 2015;20(1):20-6. http://dx.doi.org/10.117 9/1362171814Y.0000000250.

12. Saad ML, Sar MH, Barrak OS, Hussein SK, Hussein AK. Fuzzy logic model analysis of shear force in aluminium/ polyethylene lap joined by hot press. IOP Conf Series Mater Sci Eng. 2019;518(3):032007.

13. Wei ST, Liu RD, Lv D, Lin L, Lu XF, Ding SW. Effect of joint configuration on resistance spot weldability of galvanised DP780 steel sheets. Sci Technol Weld Join. 2016;21(3):178-85. http:// dx.doi.org/10.1179/1362171815Y.0000000081.

14. Zhang H, Qiu X, Xing F, Bai J, Chen J. Failure analysis of dissimilar thickness resistance spot welded joints in dual-phase steels during tensile shear test. Mater Des. 2014;55:366-72. http://dx.doi.org/10.1016/j.matdes.2013.09.040.

15. Tamizi M, Pouranvari M, Movahedi M. Welding metallurgy of martensitic advanced high strength steels during resistance 
spot welding. Sci Technol Weld Join. 2017;22(4):327-35. http:// dx.doi.org/10.1080/13621718.2016.1240979.

16. Mezher MT, Saad ML, Barrak OS, Hussein SK, Shakir RA. Multi-coupled field simulation and experimental study of AISI 316L stainless steel using resistance spot welding. J Mech Eng Res Dev. 2021;44(2):150-60.

17. Aravinthan A, Nachimani C. Analysis of spot weld growth on mild and stainless steel. Weld J. 2011;90:143-7.

18. Sar MH, Barrak OS, Al-Adili AS, Hussein SK, Hussein AK. Study the effect of filer material on microstructure of welding the carbon steel in shielded metal arc welding. J Mech Eng Res Dev. 2020;43(3):408-16.

19. Yang YP, Gould J, Peterson W, Orth F, Zelenak P, Al-Fakir W. Development of spot weld failure parameters for full vehicle crash modelling. Sci Technol Weld Join. 2013;18(3):222-31. http://dx.doi.org/10.1179/1362171812Y.0000000082.

20. Wang K, Chao YJ, Zhu X, Miller KW. Dynamic separation of resistance spot welded joints: part ii-analysis of test results and a model. Exp Mech. 2010;50(7):901-13. http://dx.doi. org/10.1007/s11340-009-9277-y.

21. Pouranvari M, Marashi SPH. On the failure of low carbon steel resistance spot welds in quasi-static tensile-shear loading. Mater Des. 2010;31(8):3647-52. http://dx.doi.org/10.1016/j. matdes.2010.02.044.

22. Wang B, Duan QQ, Yao G, Pang JC, Li XW, Wang L, et al. Investigation on fatigue fracture behaviors of spot welded Q\&P980 steel. Int J Fatigue. 2014;66:20-8. http://dx.doi. org/10.1016/j.ijfatigue.2014.03.004.

23. Eisazadeh H, Hamedi M, Halvaee A. New parametric study of nugget size in resistance spot welding process using finite element method. Mater Des. 2010;31(1):149-57.

24. Kianersi D, Mostafaei A, Amadeh AA. Resistance spot welding joints of AISI 316L austenitic stainless steel sheets: phase transformations, mechanical properties and microstructure characterizations. Mater Des. 2014;61:251-63.

25. Zhang H, Wang D, Xue P, Wu LH, Ni DR, Ma ZY. Microstructural evolution and pitting corrosion behavior of friction stir welded joint of high nitrogen stainless steel. Mater Des. 2016;110:80210 .

26. Wang D, Xiao BL, Wang QZ, Ma ZY. Evolution of the microstructure and strength in the nugget zone of friction stir welded $\mathrm{SiCp} / \mathrm{Al}-\mathrm{Cu}-\mathrm{Mg}$ composite. J Mater Sci Technol. 2014;30(1):54-60.

27. Shin B, Park S, Park J, Kim D. Effect of post-weld heat treatment on the corrosion behavior of resistance spot welded super duplex stainless UNS S 32750. Int J Electrochem Sci. 2019;14:2430-41.

28. Shin BH, Park J, Jeon J., Heo SB, Chung W. Effect of cooling rate after heat treatment on pitting corrosion of super duplex stainless steel UNS S 32750. Anti-Corros Methods Mater. 2018;65(5):492-8.

29. American Welding Society - AWS, American National Standards Institute -ANSI. AWS/ANSI C1.1M/C1.1:2012: recommended practices for resistance welding. Flórida: American Welding Society.

30. ASTM - American Society for Testing and Materials. ASTM G5-94 (2011) e1: standard reference test method for making potentiostatic and potentiodynamic anodic polarization measurements. West Conshohocken: ASTM. https://doi. org/10.1520/G0005-94R11E01

31. Husain IM, Saad ML, Barrak OS, Hussain SK, Hamzah MM. Shear force analysis of resistance spot welding of similar and dissimilar material: copper and carbon steel. Mater Sci Eng. 2021;1105(1):012055.

32. Xin SS, Li MC. Electrochemical corrosion characteristics of type $316 \mathrm{~L}$ stainless steel in hot concentrated seawater. Corros Sci. 2014;81:96-101. http://dx.doi.org/10.1016/j.corsci.2013.12.004. 